\title{
MINIMIZING DISPUTES IN LABOR CONTRACT NEGOTIATIONS
}

\author{
Owen Fairweather* and Lee C. Shaw
}

The public has a large stake in labor relations. From V-J Day to June, 1946, the direct wage loss alone resulting from strikes within the United States amounted to $\$ 1,050,000,000.1$ The economic repercussions from such a wage loss, felt as they are throughout our entire society, bring us directly to grips with the question: How can disputes arising out of the collective-bargaining process be minimized? Out of this process have come the disputes which have caused the strikes which, in turn, have torn our economy apart. Therefore, if we are to minimize the public injury which stems from strikes, we must analyze the collective-bargaining process to determine whether changes can be made in this process which will diminish disputes.

But the mere diminishing of disputes is not enough. The public may be injured as seriously by the agreements reached between the parties at the collective-bargaining table as it is by the failure of the parties to agree. The injury caused by a wrong agreement is not as direct as that of the strike which results from a failure to agree, but in the long run it may be more serious. As Professor Sumner Slichter of Harvard University has pointed out, the establishment of collective bargaining during the last decade means that the whole country has entrusted its future standard of living to the bargaining representatives of both sides.

Analysis of the current understanding of collective bargaining reveals that the process is completely unprincipled and has as its cornerstone the concept of "compromise." The statement that it is an unprincipled process means that each party approaches the conference table either with fear that the other party will attempt to take unfair advantage, or determined to assert unreasonable demands backed up by economic strength. The presence of latent fear on one side and unreasonable demands on the other, depending upon which side is in a dominant bargaining position, makes orderly bargaining difficult, if not impossible. Hence, the job to be done is to determine whether there are any basic principles which can be used as guideposts, so as to remove this fear and control unreasonableness.

If collective bargaining is to be controlled by principles, they must be principles

- A.B. 1935, Dartmouth College; J.D. 1938, University of Chicago. Member of the Illinois Bar; Partner, Scyfarth, Shaw and Fairweather, Chicago.

†A.B. 1934, University of Michigan; J.D. 1938, University of Chicago. Member of the Illinois Bar; Partner, Seyfarth, Shaw and Fairweather, Chicago.

1 The total wages lost cannot be computed, but the coal strike of 400,000 threw about $1,000,000$ persons out of work. During the same period, steel output was reduced II,400,000 tons, coal production I $13,000,000$ tons, lumber 3,150,000,000 board feet, automobiles and trucks $2,900,000$, refrigerators r,008,000, washing machines 415,000. U. S. News, June 14, 1946, pp. 13-r4. 
which both parties will in time accept. Or, if the two parties will not accept them voluntarily, they must be principles which the public, after sufficient education, will force the parties to accept. Such acceptance may be forced either by the weight of public opinion or through positive legislation.

If they are to command public support and ultimate acceptance by both sides, the principles must be based upon the public interest, rather than upon the special interests of either of the bargaining representatives. Furthermore, the principles must produce concrete answers to the typical problems that arise in a labor contract negotiation.

This article, therefore, must consider the current concept of collective bargaining, analyze the considerations of public interest involved, determine whether these considerations will support a series of simple and acceptable principles, and then apply these principles to the typical problems which arise in bargaining.

I.

\section{The Current Concept of Coliective Bargaining: \\ "Give and Take and Compromise".}

Managements have been told over and over again that the source of their diffculty with labor unions is that their representatives do not approach the conference table with a spirit of "give and take and compromise." They are blamed because they do not engage in what is called "real collective bargaining." When asked what that means, the advisors to the industrial manager tell him it means a willingness to compromise. When a dispute arises over a contract term and a representative of the United States Conciliation Service intervenes, he very naturally first finds the positions of the respective parties and then hunts for a middle ground where the dispute can be "compromised."

The War Labor Board was established on a tripartite basis for the same reason: to find solutions to problems by compromise. It was believed that the public members could find the middle ground between the positions of industry and labor after hearing the positions of both sides discussed by their respective representatives sitting as members of the board. The labor representatives on the board regarded themselves as partisan representatives of labor. ${ }^{3}$ Industry members were likewise partisan representatives. Under such conditions, the public members of the board naturally tended to solve problems by compromise between the two partisan posi-

\footnotetext{
${ }^{2}$ John R. Steelman, then Director of the U. S. Conciliation Service, said to the American Management Association on February 14. 1940: "However, no matter what the situation, the Conciliator's efforts are usually directed to reducing all controversial questions to rock bottom. Sometines this procedure results in the elimination of all points in dispute. At other times there may remain a point, or severnl points, on which both parties sefuse to yield. In stich cases, the Conciliator may suggest modifications and compromises." american Management Ass'n, Personnel Series No. 44, Conciliation and Cooperation in Collective Bargaining 18, 23 (1940). (Italics added.)

${ }^{3}$ R. J. Thomas, labor member of the National Board, said on July 28, 1944, that he did not consider his War Labar Board membership a "federal service" or "as working for the Govcrnment," but "sulely to represent labor."
} 
tions. Actually this approach satisfied no one and only accentuated the differences between the parties. ${ }^{4}$

There is no reason to believe that a compromise of two partisan positions necessarily produces a proper answer. ${ }^{5}$ The fallacy of this method can be simply demonstrated: The employer, prior to union organization, has all of the rights to manage his plant, subject only to legal restrictions. After the plant has been organized, the union presents demands upon the employer. The employer has no demands to present to the union other than the request that the union refrain from calling a strike for a given period of time. Thus the employer, throughout the development of the union movement, has been the "giving" party and the union traditionally the "asking" party. Therefore; the compromise method of settling differences amounts to the whittling of concessions from the employer. It is merely a process of raising the demand each year and obtaining part of the demand by "compromise."

This process of compromise, continued year after year, means that the employer must give more and more to the union without any apparent stopping place in sight. The fallacy of "compromise" in collective bargaining becomes clear when one asks, "When does it stop?" At what point can the employer, with assurance, say "No" to a union demand without fear that, when he goes before the conciliator or other governmental agent, a solution will not be suggested to him which will be merely another "compromise"??

It may be said that the compromise between the union and management positions may go the other way when we have a business depression. It is probably true that when business conditions are poor wage rates can be forced down, because the employer's position is then stronger. However, reliance upon the fact that compromise may favor management in a future depression is tantamount to believing that the proper collective-bargaining balance between unions and managements can

\footnotetext{
- William M. Leiserson, who was a member of the National Labor Relations Board, detected this inherent fallacy in tripartite organizations when he said on February 18, 1942: "A tripartite body with ... public members ... employer members and . . . labor members . . . tended to accentuate differences rather than to resolve them. ..." See N. Y. Times, Feb. 19, 1942, p. 12, col. 2.

The concept of compromise as the means to a correct answer has even invaded the decisions of courts. In NLRB v. George P. Pilling \& Son Co., II9 FED. 2d 32, 37 (C.C.A. 3d, I94I) the court said: "But agreement by way of compromise cannot be expected unless the one rejecting a claim or demand is willing to make a counter-suggestion or proposal. And where that is expressly invited but is refused, in such circumstances the refusal may go to support a want of good faith and, hence, a refusal to bargain." (Italics added.)

"This is shown clearly by the Steelworkers" "dollar-a-day" demand ( $12 \frac{1}{2}$ cents an hour), which produced a compromise at $5 \frac{1 / 2}{2}$ cents an hour in 1942. Little Steel Companies, I WAR LAB. REP. 325, 328 (1942). This was followed by a 25 -cent per hour demand in 1945, which produced a compromise of $18 \frac{1}{2}$ cents in 1946 . See General Order No. 1 , Office of Stabilization Administrator, \$5, I LAB. ARB. REP. clviii, clix (r946).

${ }^{7}$ Philip Murray's concept of collective bargaining is somewhat different. He said in an analysis accompanying a letter to President Truman urging the vcto of the Case Bill: "The simple fact is that the right of individual workers to quit their jobs has meaning only when they may quit in concert, so that in their quitting or in their threat to quit they have real bargaining strength. That is what is meant by collective bargaining." N. Y. Times, June 3,1946, p. 10, cols. $2,3$.
} 
be maintained only over a long period of time and only through the fluctuations of the business cycle. If we must rely upon this cycle to weaken the bargaining strength of one side or the other and to prevent excesses by either, we do not have a theory of collective bargaining which is sound.

Unless the labor unions' whittling-away on management by collective bargaining through compromise can be stopped, or the limits on that process made clear, one cannot expect management fully to accept unionism. Only if the limits are made clear will both sides settle down to really co-operative efforts. Thus, the sooner the concept of "compromise" is forgotten as the basic approach to the settlement of disputes at the conference table, the sooner real industrial peace will be obtained. ${ }^{8}$

II.

\section{The Principles of Collective Bargaining}

\section{Must be Based on the Public Interest}

There are risks in the union movement to the public generally, as well as to an individual company's management or ownership. Interestingly enough, the major hazards to management and ownership and to the public generally are precisely the same. This is extremely important, because it enables management's representatives at the conference table to adopt a position based upon the public interest which will also effectively protect the interests of the group which they directly represent. Likewise, there are risks in the union movement to employees and, for that matter, to unions themselves. These risks are often long-term risks which are lost sight of because of illusory short-term gains. Like the hazards to the public, those to the employees are much the same as the hazards to management and ownership. Let us briefly consider the reasoning which demonstrates that management's interests, employees' long-term interests, and the interests of the public in collective bargaining are identical.

\section{A. Industrial Efficiency Means a High Standard of Living}

The public is interested in industrial efficiency just as much as, if not more than, the management and the owners of an individual company. The London Economist in August, $1944,{ }^{9}$ called upon the British Government to organize a campaign to inform Great Britain of the need to raise British production to the same level per worker as in America so as to give Great Britain a standard of living equal to that of this country. The Economist maintained that the alternative would be for the British standard of living to drop to the level of that of Germany and other Euro-

a "The diffeultics in solving the problems created by the shift of power from business to labor are enormous. The most formidable obstacles to these changes arise from the necessity of recognizing new facts and problems and dropping many ancient preconceptions and traditional points of view. So rapid and recent has been the shift of power that many employers and workers do not yet realize what has happened. They still regard trade unions as underdogs." Slichter, Trade Unions in a Free Society, Duily LAs. Rep. (BNA): D-I (October 8, 1946).

- A Policy for Wealth, 147 Economist 236, 237 (1944). 
pean countries. This English newspaper stated that the average American worker produces in one hour "one and one-half to two and one-half times as much wealth as the British worker," and consequently enjoys more leisure and better conditions.

This statement expresses the simple rule that a nation's standard of living depends on its productivity per man-hour. ${ }^{10}$ In other words, high productivity or high efficiency means a high standard of living, and a high standard of living is in the public interest. Because this is true, union representatives should not make demands at the conference table which interfere with the efficiency of the plant, for in doing so they endanger the standard of living of their members. Management should be duty-bound to resist such demands if they are made, for high efficiency means profitability, and such a position on the part of management is consistent with the public interest. The government in its participation, from conciliation throughout whatever system is devised, should adopt the same policy if it is to perform its duty. Its duty is obviously to protect the public interest, which means to preserve a high standard of living, which in turn requires high efficiency and high productivity.

The first principle, therefore, is: The negotiators of a labor contract must not make any agreement which injures or limits industrial efficiency.

\section{B. Incentives are Necessary for the Creation of Jobs}

Workers unemployed become a public charge. The public, therefore, is interested in the maintenance of job opportunities for all who are able and willing to work. It follows that it is to the public interest to preserve the incentives which are necessary for the creation of jobs. This problem has two aspects. First, penalties placed upon management which are deterrents to healthy expansion reduce the number of jobs industry will create; and second, reduction of the profit return below the level that will properly reward the risk-taking investor will reduce the flow into industry of the new money which stimulates new growth and, hence, creates new jobs.

The nation's industrial plants are now producing goods to satisfy consumer demand built up during the period when our economy was producing war goods. When this initial job is finished, there will come a rapid drop in demand for the goods now being produced. The only way to provide jobs for the persons who will be displaced as demand diminishes is to start producing new products in the place of old. Neither unions nor the government can make real jobs. They can only assist. As Alfred P. Sloan, Jr., of General Motors Corporation, has aptly said: "Political promises do not create jobs. ... Jobs flow from a combination of capital, management, and opportunity, and from nothing else. . . . Without these ingredients there can be no jobs."11

${ }^{20}$ Some American labor leaders understand this fact. Walter Cenerazzo, President of the American Watch Workers' Union, said: "Now the unions have got to help capital and management carry the load of more goods, more services and more welfare for the American people." Reader's Digest, Dec. 1946, p. 27.

21 The Importance of Jobs, II VITAI SPEEches 115 (1944). Some government spokesmen have had a contrary view: "The other thing that I think the Government ought to guarantee is some kind of job to every person who can work. If a person has done all he can to find a job and still can't find one, the Government ought to offer him 2 job." Goldenweiser, Postwar Problems and Policies, 31 Feb. Res. Burl. I12, II5 (1945). 
Technological improvements resulting from the war will cause some pre-war businesses to go bankrupt and new businesses to be born. In fact, new business activity must constantly be born if we are to prevent a serious slowdown of the industrial pace and a reduction in the total number of jobs. Thus, changes in the concentration of capital and labor from old to new fields necessarily take place. These shifts must be made rapidly. Only if the growing fields of industrial activity are invigorated by new investment will total employment remain constant or expand.

The shifts and changes which must take place will cause some people temporarily to lose their jobs. Since no one can be sure who these people will be nor how long they will be out of a job, thousands of people today are worried about their economic future. This widespread consciousness of the uncertainties of the future, stimulated by labor unions, ${ }^{12}$ has aroused a passion for any plan or proposal for economic security. ${ }^{13}$

Since industrial change involves some elements of insecurity, proposals for economic security are often plans to prevent change. Yet change is essential to full employment and national economic health. Therefore any effort, whether by unions through the collective-bargaining process or by government through regulatory restrictions, to impose a stability upon industry which runs counter to the adjustments demanded by progress will lead to a rigid economy. The ultimate disruption of such an economy when the effort finally fails-as fail it must-will destroy the very security which was the objective of the restrictions placed on industry.

Therefore, we find at the conference table a struggle between two points of view: that of the union negotiators, who often believe that the highest standard of living and security for the largest number come from an industry which is regulated so as to prevent the changes that cause insecurity, and that of the industrial manager, who believes that the highest standard of living and security for the largest number come from complete freedom of action by management. ${ }^{14}$

${ }^{12}$ George F. Addes, secretary-treasurer of UAW-CIO, said: "From an economic standpoint, the average man feels even less secure than he did a year ago. Developments have taken place which shake to the very core the confidence of the common man in the ability and even the desire of many of our ceonomic and politieal leaders to plan an economy in which there would be some semblance of security for the wage earner." United Automobile Worker, Dec., 1946, p. 5, col. 3.

18 "The Government should guarantee to every American a minimum standard . . . below which no person in this country needs to fall under any circumstances. . . . What we need is better organization among the lower income groups. This should be a broad objective of public policy." E. Z. Goldenweiser, Economic Advisor to the Federal Reserve Board, loc. cit. supra, n. II, at II5.

${ }^{14}$ This struggle has been called by Mr. Harold Laski, chairman of the British Labor Party, liberalism vs. socialism. "We have come to the boundaries of the final dividing line between liberalism and socialism. There is no middle way. Free enterprise and the market economy mean war; socialism and planned economy mean peace. All attempts to find a compromise are a Satanic illusion. We must plan our civilization or we must perish." N. X. Times, Dec. 4, 1945, p. I, col. 6; p. 5, col. 3.

As Mr. Laski uses the word "liberalism." it is synonymous with a belief in free enterprise and a free market.

The word "liberalism" is a popular symbol. It has always meant change, but, in addition, most liberal movements have been attacks against governmental direction and control. One of the early liberal movements was the departure from autocratic government exemplified in the Magna Charta. The limitation upon central governmental control incorporated into the American Constitution was another result of a liberal movement. If socialism means governmental direction of the cconomy, it mus properly be opposed by "liberals." 
The proper approach falls between these points of view if deterrents to change are not to be imposed on industry. Put new development and efficiency of industry in the forefront of our thinking and acting, and then provide supplementary but adequate measures to protect those individuals who are temporarily displaced in the process of industrial change. Such measures must not restrict change, however, or long-term security will be lost.

In addition to opposing unreasonable restrictions on change, or the "planned economy," thinking people are becoming conscious of the importance of retaining a strong profit incentive in industry. The proposals to abolish the corporate income tax because it has a deadening effect upon American industry by removing a substantial part of the profit incentive are illustrative of this trend. Since economic development is stimulated by the possibility of profits, the profit incentive must not be destroyed. If it is destroyed, the necessary expansion of industry will lag and will not offset the inevitable postwar contractions, and the industrial machine will slow down.

If profits in any given industry appear large at any given time, they serve a real social purpose. High profits mean unsatisfied demand for the industry's products. They lure into that industry new and expanded enterprise designed to satisfy that demand, thereby creating more jobs. If high profits in such an industry are siphoned off too quickly through wage levels or tax rates out of proportion to those of older, lower-profit industries, they will not accomplish this important function. No social injustice occurs during this development period, because the risk-taker who ventures into new fields deserves a high profit until others entering that field catch up and create a competitive situation, with the result that profits drop to a more normal level. ${ }^{10}$

For the reasons outlined here, the protection of the profit incentive has been recognized as essential to the maintenance of a healthy industry and the creation of unstinted job opportunities. Public works programs supported by taxes are no adequate substitute for new industrial growth. In the last analysis, the wage earner must rely upon a healthy industry for security. ${ }^{10}$

Thus, the second principle is: Collective bargaining must not be permitted to impose restrictions on industrial change nor to destroy the profit incentive.

${ }^{15}$ Floyd A. Harper, The Crists of the Free Maziket (National Industrial Conference Board, 1946) 19, concerning the assumption of government control of industry which would include the assumption of the risk-bearing function: "If Uncle Samuel or some other benevolent gentlemen assumes the risk, the equivalent of profit is still there and has mee ely been moved so that all of us or some one else bears it; its existence and cost are not changed, in fact, its cost will increase because we become careless about success when failure belongs to some else."

${ }^{18}$ The UAW-CIO International Union Policy (April, 1946) states: "We should not concern ourselves with whether the corporations are protected in maintaining their high profit levels. The corporations are adequately capable of protecting their own profit levels without any help from labor spokesmen." Daily Lab. Rep. (BNA) E-I (April 19, 1946).

Walter Cenarazzo, President of the American Wateh Workers Union, understands the value of profits. "Only out of profits can our employers give us better tools for better production, out of which we can get our cut in bigger wages. We have got to help our employers make good profits," Readers Digest, Dec. 1946, pp. 27,28 . 
C. Wages and Purchasing Power

The public is interested in the preservation of purchasing power, for purchasing power is essential to continued production, which, in turn, is essential to continued and increasing employment. It was belief in this theory that led to the "pumppriming" public works programs of the New Deal, resorted to in an effort to pull the country out of the last depression. ${ }^{17}$

Collective bargaining will perform a valuable function if it effectively prevents a sudden drying-up of purchasing power. Recent history has shown, however, that while unions through collective bargaining have been able to obtain large wage increases, such increases have been followed almost immediately by price increases. This has caused many to question the advantage of the wage increases to the union members and to emphasize the injury which they have caused to another segment of the public-the individuals living on a fixed dollar income.

Mass purchasing power can better be maintained by full employment even at constant wage levels than through wage increases with reduced total employment. If collective bargaining forces wage rates up too rapidly for certain special groups, the total number of jobs may.be lessened because the remaining persons will be unable to buy the goods produced at the higher prices which will be charged; thus the total purchasing power may be decreased. This will result in non-consumption of the goods produced and a serious threat to our economy. ${ }^{18}$

While the purchasing-power theory of wage increases may have some validity in a depression era if properly controlled, it is completely invalid as an argument for unlimited wage increases during a period of inflation. Inflation, by definition, is a condition in which there exists more purchasing power than goods to purchase. In such a period the emphasis must be on increased production, not on increased purchasing power. Unrestrained collective bargaining in an inflationary period when labor is in short supply thus carries the threat of unbalancing our economy by improperly increasing wages. ${ }^{19}$ Thus the third principle is: Collective bargain-

\footnotetext{
${ }^{27}$ The purchasing-power theory is the unions' theory. Philip Murray said: "The first decision that must be made is that America shall be a country of high wage standards, where the masses of the people have sufficient purchasing power to create a great domestic market for cver-expanding production." N. Y. Times, January I, 1946, p. 20, col. 5.

Walter Reuther said: "America's postwar problem is not production, it is the maintenance of purchasing power so that the American people can buy back the abundance they can produce." N. Y. Times, November 25,1945, p. 36 , col. 3 .

18 The purchasing-power theory as a union argument is valid only if one assumes that the propensity' to consume is greater among wage-earners than among other economic groups.

${ }^{10}$ The Nathan Report, which is the statistical springboard for the 1947 wage drive of the CIO, argues that profit return is too high. Wage increases, Nathan says, are needed to create buying power. The most obvious fallacy in this report is that the average profit level assumed by Nathan to be correct was the 1936-39 average profits of all corporations. This period included abnormally depressed years. Furthermore, the 1946 profit levels, especially in retail sales, are undoubtedly inflated because of scarcities of goods. He mentions, but fails to apply, the fact that profit levels vary between industries and individual companies, which makes a report based on averages inapplicable to individual companies. The conclusion that a $25 \%$ wage increase can be granted throughout industry without price increases would be laughable in view of the price increases that immediately followed wage increases in 19.46 if it were not for the fact that millions of people will believe the conclusion.
} 
ing should not reduce the nation's purchasing power by raising prices or reducing wages too rapidly.

III.

The Real Parties to a Labor Contract Are Not the Negotiators

The real parties interested in a labor contract are three: the employees or wagecarners; the owners or investors; and the consumers or the general public. The agreements that are made and those that are not made at the conference table affect all of these groups.

The negotiators are the industrial managers and the labor union representatives. They act merely in representative capacities. It is important to discover what the natural motivations of these two negotiating representatives are in order to determine whether or not either one or both of them are naturally motivated to obtain collective contracts consistent with the public interest.

\section{A. The Union Negotiators}

Modern unionism is big business: over fifteen million employees are members, out of a potential of about thirty million wage-earners eligible for membership. Forty-five per cent of this membership is under closed- or union-shop contracts (compulsory unionism), and 77 per cent under some form of union security. ${ }^{20}$ The income of unions is measured in millions of dollars per month. ${ }^{21}$ At $\$ 1.50$ per member per month, the income from General Motors employees or Carnegie-Illinois Steel Corporation employees is a staggering figure. The salaries of the top union officers are high: Petrillo, $\$ 48,000$; Lewis, $\$ 25,000$; Tobin, $\$ 30,000 .^{22}$

Unions have become big within the last ten years. Much of this growth started with the spontaneous organization of employees for bargaining purposes, but now unions continue to grow through organizational drives. Examples are the organizational drives in the South by both CIO and AFL. In one plant of 2,000, it cost $\$ 25.83$ per worker to organize the employees into the UAW-CIO.

In order to organize people, union organizers naturally make promises of higher wages and better conditions. Also, union organizers must demonstrate that employees need a union; hence, they create in the minds of employees a fear of economic insecurity and a fear of managers, who are described as hostile capitalists bent on the destruction of working people. It is hard to sell unionism by telling workers that the management is fair.

These organizational promises and the general attack upon management, which are deemed necesary organizational steps, have produced a groundswell of rank and file pressure for more wages and more security. This was frankly stated by

\footnotetext{
${ }^{20}$ In 1945, twenty-nine million persons were eligible for union agreement coverage, and $48 \%$ were covered by contracts. United States Bureau of Labor Statistics, The Extent of Collective Bargaining and Union Recognition in 1945, Collective Bargatning Negotiations and Contracts (BNA) p. 15:1.

21 Estimated at $\$ 26,950,000$ per month from 13,000,000 dues-paying members by Victor Riesel, Labor Editor, New York Post. Labor Is Big Business, 6I AM. Mercury 728 (1945).

${ }^{22}$ Tobin also receives "business and pleasure traveling expenses for self and wife." lbid.
} 
Joseph Padway, General Counsel of the AFL, when he said: "That is trade unionism. We want more and more. Continually more. More wages; more leisure; and more of the goods of life that we make...."

Add to this groundswell of demand the fact that unions are essentially great political organizations. The leaders are elected by the rank and file. ${ }^{23}$ Therefore, one leader must outdo the next in his demands in order to insure continued loyalty of his constituents. ${ }^{24}$ The necessity to maintain position in unions by producing more means that by propaganda employees must be stimulated to want more to such an extent that they will strike. The willingness of the rank and file to strike is the surest way for the leaders to get more. Hence there develops a vicious spiral of increases in wages, the creation of demand for more increases, further increases, further demands, etc.

Finally, there is the minority of union officials who subscribe to the communistic philosophy either officially or unofficially. ${ }^{25}$ Stated simply, this is the philosophy that capital and labor are unalterably opposed, and that if conflict can be stimulated the capitalistic system will eventually destroy itself, with the result that the people will be able to take over industry and run it on a planned-economy basis with political bosses (former union leaders) in control, rather than managers. The prevalence of this philosophy merely adds fuel to the union leader's incentive to generate demands in order to continue to grow.

The motivations of the union negotiators thus appear to be many and complex. These motivations must be understood by the management negotiators if an adequate $\mathrm{job}$ is to be done at the conference table. One thing is clear: the natural motivations all lead in one direction. That is, "more, we need more." It must be concluded that union negotiators have no natural incentives to strike a balance between the interests of the three major groups involved.

\section{B. The Management Negotiators}

For the purposes of this analysis, management, as is true in most cases, is assumed to be a professional management, rather than a management composed of owners.

Professional management desires to operate an efficient plant, sell a large volume

${ }^{28}$ Daniel T. Pierce, assistant to the president, Sinclair Oil Company, said: "One of the first things we learned was that union officials, national as well as local, were merely title holders. They were unable to lead, even when they desired to do so. Thy were puppets of the rank and file. Over and over again we were told, in confidence of course, by the unions officials that they knew demands or grievances were unreasonable but that they, the officials, had to present them because their constituents so insisted." How the Union Disillusioned Us, Factory Man. and Maint., Jan. 1946, p. 94, col. I.

"Two transportation union presidents, for example, stopped the nation's railroads in 1946 because an emergency board, appointed by the President, awarded them no more than a board of arbitration gave eighteen other railroad unions. Four hundred thousand coal miners were called out on strike in 1946 after their president rejected a wage increase of $181 / 2$ cents an hour, and millions of non-miners were thrown out of work in order to win gains beyond those achieved by other unions.

${ }^{25}$ The Communist Fifth Column, Chicago Journal of Commerce, June 24-July II, 1946; CommunisT Infiltration in the United States (Chamber of Commierce of the United States, 1946); J. Edgar Hoover, Red Fascism in the United States, American Mag., Feb., 1947, p. 24. 
of products, and make a good showing on the balance sheet for the owners. To do this, it must:

1. Pay a wage high enough to obtain the proper skills, yet not so high that costs become noncompetitive and the products produced cannot be sold. A professional management is under an incentive to raise wages as wage levels in the area go up; ${ }^{28}$

2. Fix a price for the product which will be low enough to obtain a large volume of sales and low unit costs, ${ }^{27}$ but high enough to pay wage costs and insure an adequate profit;

3. Pay a high enough return to the investor to insure future investment when it is needed and to insure management's own job security, but not so high as to prevent allocation of capital for improvements in machinery, plant expansion, etc.

Professional managements thus appear to be under natural incentives to balance the shares received by each of the three interested groups-the workers, the consumers, and the investors. The concept of the management negotiators as "balancers" is of prime importance in the collective-bargaining process. ${ }^{28}$ Since managements are under natural incentives to strike a balance, they, in fact, become the best representatives the public has at the conference table.

\section{IV.}

\section{The Labor Contract-What Should It Be?}

Before we deal in detail with some of the major problems that arise in the negotiation of a labor contract, one further preliminary matter should be considered. What is the purpose of a labor contract, considered as a total document?

A labor contract is a statement of policy which is established through negotiations and which is to remain in effect for a fixed period of time.

If it is a policy to control the relationship between the parties, it must clearly set forth the rights and obligations of the parties so that they can properly perform their respective functions. Therefore, it is necessary to examine the functions of the parties to a collective contract.

\section{A. The Management Function}

Management's prime function is to manage-that is, to plan the work and to direct the working forces. Management is a group of individuals trained, at great expense, in industrial "know-how." If management does not do its job properly, the plant will not be as efficient as it would otherwise be. Management must have the right under the contract to manage the plant efficiently if the efficiency principle considered above is to be followed.

20 "Bidding for labor among employers has been more active than most economists have assumed. The picture of a helpless wage-earner dealing with a large employer, frequently pictured by economists, is not casily reconciled with the wage and price movements of the last century." Slichter, Wage Policies, 22 ACAD. Por. Sci. Proc. 3 (1946).

${ }^{27}$ Ford Motor Company's price policy is an outstanding example of fixing the price for mass sale and forcing the manufacturing costs down to the price.

${ }^{2 x}$ Educational programs for employees to explain to them how modern business operates are essential to the proper handling of an individual company's labor problem. 
Management is charged with carrying out many policies. One of these policies is contained in the contract with the union. Therefore, it becomes management's job to manage the plant under this contractual policy. The management is always the "acting" party; there is no basis for the idea that, because a labor contract exists, the union shares jointly the obligation to manage the plant efficiently. That is solely management's obligation.

Many uninitiated observers of the labor union movement believed that as unions matured they could take on a joint function with management in running the everyday affairs in a plant. The fallacy in any such arrangement is revealed very directly by William Leiserson, formerly a member of the National Labor Relations Board and the Railroad Mediation Board, who said of the ill-fated attempt to administer the Office of Production Management under the dual leadership of Knudsen and Hillman:

... The President was asked what would happen if they disagree. He answered they would work together and make joint decisions. This was taken as an indication that the government intended the business of defense production to be a joint co-operative enterprise of employers and workers on an equal partnership basis. . . . There developed a confused organization and administration.... The arrangement had to be discarded....

In retrospect it is easy to see the mistake that was made in establishing the doubleheaded directorship of the Office of Production Management. It was due to inadequate analysis of the job that was to be done and failure to distinguish functions. We do not have to be versed in the philosophy of management to understand that it is not practical to mix the policy-making functions of an organization with the operating functions.

It does not work and it satisfied no one. It leads to maneuvering and argument. It leads to maneuvering and argument about policy among operating officials whose sole duty should be to carry out promptly and efficiently the operating orders. . . . It turns a production organization into a debating society.

The basic principles which are to guide the company in its labor relations are established in the union contract. Collective bargaining takes place when the basic policies are hammered out. From that point on, management must manage or the plant managers, instead of managing, become debaters in a debating society.

The concept of the labor contract as a contractual policy for a period was challenged in the most serious manner in a recent National Labor Relations Board case. $^{29}$ The board found the company guilty of a refusal to bargain under section $8(5)$ of the Act on (I) an employee's manual of plant rules, ${ }^{80}$ (2) a change in working conditions in a department, (3) the company's policies concerning subcontracting work to outside contractors, (4) working schedules of maintenance employees, and (5) working schedules of pit-crane hands.

The company did not deny that it had failed and refused to bargain with the

"Timken Roller Bearing Co., yo N. L. R. B. 500 (1946).

10 This finding was not part of the final order because the right of the management to make neeessary rules under the contract had been upheld in a final and binding arbitration, but the Board disagreed with the arbitration award and the refusal to negotiate the rules was found, in the opirion, to be' a refusal to bargain. 
union on these matters, but defended on the ground that, at the time the refusals to bargain took place, it had a contract in effect with the union and, therefore, the union had no standing before the NLRB in as much as its rights to bargain under section $8(5)$ were exhausted for the life of the contract when the contract was signed. At first blush, this decision appears to upset completely the concept that the labor contract is the master policy and that management can manage under it for the life of the contract. It appeared that the board was opening the flood gates and that managements would be forced to bargain collectively all the time. In that event, no one party would have the right to manage the plant; management would be a joint responsibility requiring constant negotiations and debate. If this case is construed as destroying the concept of stability for the period of the contract, stable relations and industrial peace will be almost unobtainable. The case need not receive such a construction, however. It is conceivable that an employer and a union could agree to a contract covering the recognition of the union only. Three days later, the company and the union could execute a contract covering seniority rights only. Three days later, the company and the union could execute a contract covering wages only, and thus the collective-bargaining process could continue until the parties finally agreed that all of the basic policy provisions had been worked out and that they would forego collective bargaining for a stated period of time. It is recognized by the National Labor Relations Board that unions can by contract give up their right to bargain..$^{31}$

What the case does mean is that, if management's representatives at the collectivebargaining table are to obtain stability and are to avoid the creation of a "debatingsociety" condition in the plant, they must insist, once a full and complete collective contract has been negotiated, that the parties agree that the contract is a full and complete agreement and that there shall be no further collective bargaining for the life of the contract.

\section{B. "Management Right" Provisions}

Since efficient operation is necessarily a management function, the provisions of a labor contract should make it clear that management has the rights which are necessary to the performance of this function. It is interesting to note how this functional concept of management's rights has been reflected in the War Labor Board's decisions and in arbitration awards, which together are the only source of "common law" on rights of unions and managements under labor contracts. In considering various contract provisions, we have set forth quotations from these opinions to demonstrate that this "functional approach" is a practical approach to labor contract drafting.

\section{x. The Selection of Supervisors}

The selection and control of the supervisory force by management is necessary if the plant is to be managed efficiently. This was recognized by the War Labor

${ }^{32}$ Briggs Indiana Cerp., 63 N. L. R. B. I270 (1945). 
Board, which vested selection and control of supervisors exclusively in the management.

In the Stanolind Oil \& Gas case $e^{32}$ a question of discipline of supervisors was involved. The board unanimously held that the "supervisor's removal or transfer is solely the prerogative of management." In Long Lake Lumber Company ${ }^{33}$ the referee said: "... the union cannot have a direct voice in the management of any company which does not wish to give it that voice and it would be against public policy to order the removal" of a particular individual as superintendent. ${ }^{34}$

The functional approach to management's rights, in a case involving management's right to select supervisors, was clearly relied upon by Dean Young B. Smith of the Columbia Law School in the Wright Aeronautical Corporation arbitration: ${ }^{3 n}$

... It is management which is responsible for results. This being so, the management should be free to manage. To permit compulsory arbitration in matters affecting the business policies and the selection of men to direct the execution of those policies would, in effect, force upon management judgments of persons chosen as arbitrators who may know little or nothing about the business and plant problems involved and who bear no personal responsibility for the consequences of their awards. The operation of a great industrial plant like the Wright plant ... is a task which can be performed only by men familiar with its organization and skilled in the work that is done. Tampering with the machine by unskilled hands would be a dangerous procedure and is not to be encouraged.

\section{Discipline of Employees}

The War Labor Board ruled that management has the right to discipline employees in the first instance, and that the union has only the right to challenge the propriety of such discipline. This was clearly demonstrated by the board's decision in the Brewster Aeronautical case, ${ }^{36}$ where the union had obtained from the management through collective bargaining a clause which provided that the company must obtain the agreement of the union before it could discipline an employee. Because this clause took from the management its ability to manage, the board, contrary to its normal policy of supporting agreements reached by the parties, eliminated it from the agreement and returned to management the right to discipline the employees, permitting the union to challenge the disciplinary measure only after it had been taken.

In General Motors Corp., ${ }^{37}$ the National War Labor Board refused to limit the company's right to discipline by requiring prior consultation with the union repre-

s2 20 WAR LAB. REP. 2 II (1944). In this and the following quotations emphasis has been supplied by the authors.

${ }^{33}$ I2 WaR LAB. REP. 352 (I943).

"See also Allis-Chalmers Mfg. Co., 7 WAR LAB. Rep. 297 (1943) and Winchester Repeating Arms Co., 6 War LAB. Rep. 359 (I943).

${ }_{35}{ }_{13}$ L. R. R. MAN. 2580, 2582 (1943).

${ }^{30} 12$ WAR LAB. Rep. 40 (1943).

${ }^{27} 22$ WAR LAB. REP. 233 (1945). 
sentatives. It relied upon the same functional view of management's rights when it said in the Norge Products case: ${ }^{38}$

Management's right to discipline employees for cause as necessary for the efficient operation of its business is recognized by this determination. . . . To say that management has no right to impose discipline in such a case would impose an insurperable obstacle in the way of management's performance of its essential function.

\section{Plant Rules and Regulations}

One of the important rights necessary to the efficient operation of a plant is the right to make rules and regulations. If rules regarding plant routines cannot be made without joint agreement between the company and the union, the ability of the company to manage the plant is infringed. The National War Labor Board recognized the employer's right to make such rules, one of its clear rulings on this subject being the Rueben $H$. Donnelley Corporation case. ${ }^{39}$ The panel recommended that if agreement could not be reached on the rules, they be submitted to an arbitrator for final decision. The board rejected the panel's recommendation and entered an order with the following provisions:

The company shall have the right to formulate such rules as may be necessary for the proper conduct of its business, provided such rules shall not abridge any rights of the cmployees as guaranteed by the terms of the collective bargaining agreement.

The company shall have the right to discipline any employee for any violation of disciplinary shop rules.

Any complaint that any employee has been unfairly treated or that he has been.improperly disciplined, or any allegation that the rules formulated by the company for the conduct of its business have not been fairly applied may be taken up as a grievance in accordance with the grievance and arbitration procedure.

\section{Determination of the Number of Employees in a Crew}

One of the most significant cases ever decided by the National War Labor Board was that of the American Smelting \& Refining Co. ${ }^{40}$ The Sixth Regional Board (Chicago) had ordered the company to submit to arbitration the union's request that additional workers be employed in the furnace room. This order was appealed and the National Board said:

That portion of . . . the directive order dated June 29, I944, which directs that the union's request for the employment of additional workers for the furnace room be taken up under the grievance procedure, including arbitration, is set aside for the reason that the request as stated is not a proper subject for arbitration. . . .

This is an unmistakable decision that the establishment of the size of the working crews is a management function. It is consistent with the view that management

88 I5 WAR LAB. REP. 65I, 654 (1944).

s9 I5 WAR LaB. Rep. 55I, 553, (1944). However, see Timken Roller Bearing Co., 70 N. L. R. B $500(\mathrm{I} 946)$.

${ }^{10} 21$ WA3 LAB. Rep. I63 ( 2945$)$. 
must have exclusive jurisdiction on such questions if the plant is to be efficient. ${ }^{41}$

\section{Establishment of Piecework Rates}

This is a live subject because unions are asking for the right to participate in incentive-rate setting. However, if the union obtains a veto power over the establishment of incentive rates the incentive program cannot properly be carried out. If each rate is to be established by bargaining, it will be impossible to set rates in accordance with any scientific or consistent method. Management, therefore, would be deprived of this method of obtaining efficiency from the plant."

On this point, the War Labor Board took a strong position. In the Cramp Shipbuilding case, ${ }^{43}$ the commission eliminated the practice of guaranteeing incentive rates 25 per cent above base rates; removed the joint control of company and union over day-to-day adjustments of piecework rates; provided that pay guarantees should be applied on a weekly rather than a daily basis; and provided that no incentive payment should be made for work which did not meet quality standards. The commission said:

$U_{p}$ to the present time the union has held all the cards in this type of bargaining. By this decision, the company is placed in the driver's seat. If the company representatives fulfill their obligations in an equitable manner, the results should be satisfactory.

In the Borg-Warner Corporation case, ${ }^{44}$ the union asked the Regional Board to order that the company negotiate any changes from hourly rates to piecework rates with the union and that an agreement be reached before such changes were made. The board denied this request and placed its decision squarely on the basis of management rights. This is shown by the fact that the labor members of the board said in a dissenting opinion:

In this case, the company claims its right to change hourly rates to pieccwork prices, without union approval, as a management prerogative. ... Such management prerogatives belong to the dead feudalistic past. ...

The board's denial of the union's request was a refutation of the labor members' position.

\section{Job Evaluation}

The board granted to employers the right to define and evaluate the job. ${ }^{15}$

${ }^{12}$ Unions do not subscribe to limiting crew sizes to the efficient number. If efficiency is socially important, control over this and related questions must be placed in the management's hands. See Sumner H. Slichter in Union Policies and Industrial Management (1941), listing nine ways in which labor unions "make work."

$\$ 2$ The UAW-CIO would not make a good partner to handle day-to-day rate questions, for it said in its national policy statement (April, 1946): "We must... continue our efforts to eliminate the piece-work system entirely." Daily Lab. Rep. No. 79: E-1, 2 (April 19, 1946).

47 WAR LAB. REP. 753, 765 (1944).

" if War Lab. Rep. 449, 453 (I944). See also Firestone Tire \& Rubber Co., 9 War Las. Rep. 726 (1943); McQuay-Norris Mfg. Co., 9 WAR LAB. Rep. 538 (1943). (1943).

${ }^{45}$ Gray Mfg. Co., 7 WAR LAB. Rep. 401 (I943); Celanese Corp. of America, 7 War La8. Rep. 290 
Although a "basic change" in the job-evaluation plan was made subject to mutual agreement, the board, in the United Aircraft Corporation case, ${ }^{46}$ directed the following clause:

It is understood that the determination, operation, and administration of the job-evaluation plan effective in the company's plant is a function and responsibility of management....

In Western Electric Company, ${ }^{47}$ the board adopted the panel's report denying equal participation by the union in the administration of the company's job-evaluation plan. The panel said:

The job evaluation plan could not function long if there were divided direction and every basic decision required joint agreement. The day-to-day operations of the plan must be left to the company to be carried on through the specially trained staff which it organized for this very purpose.

\section{Merit Rating of Employees}

The National Board recognized the functional principle. in connection with merit rating of employees. In the Consolidated Vultee Aircraft Corporation case ${ }^{48}$ it rejected a union demand for joint wage review for each employee every six months. The board's opinion, written by Public Member Lewis M. Gill, says:

The main controversial item in this dispute had to do with the union's demand for joint participation with the company in the determination of merit increases and promotions. The management objected to making these matters the subject of joint determination on the ground that it is traditionally and properly a function of management to determine merit increases and promotions subject to the union's and the employee's right to contest any allegedly unfair determination through the grievance procedure. . . .

After a lengthy discussion of this hotly contested issue, the Board has sustained the management's position and rejected the union's demand for a joint determination of merit increases and promotions, with the labor members dissenting. . . .

The labor members have submitted a dissenting opinion protesting against the Board's failure to provide for joint determination of merit increases and promotions and have asserted that various court decisions indicate that the National Labor Relations Act prohibits unilateral determination of these matters by the company where there is a collective bargaining agency in the plant. Without burdening this opinion with an exhaustive legal analysis of this point, it is the view of the majority that the decisions referred to do not actually bear upon the point at issue here. As we read the decisions, they hold in substance that individual bargaining between the company and individual employees is only proscribed when it constitutes an evasion of collective bargaining with a duly designated union over rates of pay. Where, as in this case, rate ranges have been established through regular collective bargaining procedures, we do not think that the decisions go so far as to hold that there must be joint bargaining over all merit increases and promo tions within the framework of the ranges of rates thus established.

" 21 WAR LAB. REP. 137 (1945).

it ig War Lab. Rep. 128, I35 (1944).

${ }^{18}$ I6 WAR LaB. ReP. I59, I6I-162 (1944). 
That original merit rating is a function of management was the board's position in Gerber Products Company.99 The opinion states in part:

The union demands the abolition of the present merit-rating system. It does so on the ground that the employees do not know who makes the merit ratings and never see these ratings.

The panel deemed this demand of the union to be unwarranted and the majority of the Regional Board concurs in the recommendation of the panel. In merit-rating systems generally the employees do not know who makes the ratings. While it may be desirable that the employees should know how they are being rated, this can by no means be considered a right of the employee. Merit ratings are made primarily for the benefit of the employer. It would be a serious encroachment upon management rights if its rights to rate employees in accordance with its own standards were forbidden. We deem such a restriction to be unwarranted.

\section{The Management Clause}

The management clause is actually the least important method of protecting management's rights. The reason for this is that management has all management rights before the collective bargaining contract is signed, and if no management clause existed in the contract, management would still have all the rights not bargained away elsewhere in the contract. Arbitrators normally hold that the management clause merely sets forth residuary rights and that it is subordinate to the other provisions of the contract. ${ }^{50}$ The management clause, however, is often very helpful in settling grievances, and for that reason it should be included in the contract. To prevent infringement upon management rights in the future, such a clause should begin with a provision to this effect:

It is understood and agreed that management possesses the sole right to manage this plant and that all management rights repose in it, but that such rights must be exercised consistently with the other provisions of this contract. These rights include but are not limited to the following: ... .

After such a preamble, all of the basic management rights should be listed, as in the following clause taken from the directive order in the United Aircraft Corporation case: ${ }^{\text {i1 }}$

It is recognized that the company has and will retain the sole right and responsibiljty to direct the operations of the company and, in this connection, to determine the number and location of its plants; the schedule of hours of work; the schedules of production; the methods, processes, and means of manufacturing; and to select and hire new employees, including the right to make rules and regulations governing conduct and safety: Provided, however, that none of these functions of management shall be exercised so as to abrogate or nullify any specific provision of this contract. It shall also have the right and responsibility to suspend or discharge any employee for just cause and to transfer or lay off because of lack of work or other cause. ...

10 12 War Lab. Rep. 74, 77 (1943), aff'd 12 War LAB. Rep. 4.40 (1943).

- Bechtel-McCone Corp., 14 L. R. R. MaN. 2640 (1944).

21 is War. Lab. ReP. 9, to (August I, t944). 


\section{Hours of Work}

The hours of work in many companies can be fixed by contract without interfering with management's function. However, where frequent changes were necessary in order to manage the business efficiently, the War Labor Board granted to the management the right to fix the hours of work. In the Fairchild Engine and Airplane Corporation case, ${ }^{52}$ the National Board directed:

Determination of the daily and weekly work schedules and the starting times of such schedules shall be made by the Company, and such schedules and starting times may be changed by the employer from time to time to suit varying conditions of the business after consultation with the Union.

It should be noted that the functional approach to management's rights means that management derives its rights from its obligation to manage efficiently so that the national standard of living will be improved. Heretofore, management's rights have been conceived of as prerogatives. The very word "prerogative" is an outgrowth of the feudal system, as it was a term attached to the rights of royalty. As applied to labor affairs, it means. the rights which grow out of ownership. The legal concept of ownership is "control."63 For example, when an individual has full ownership of a piece of land, he has complete control." When he places a mortgage upon the land, his control over the property is diminished, even though he may still own the title. The statement that management's rights grow out of ownership means that the owners, who have all rights because they own the business, delegate these rights to management. This theory brings unnecessary emotion into collective bargaining. Each challenge to the management's right to "control" is conceived by management and the owners to be an effort to take over control. Each resistance of management to such encroachments upon its prerogatives is decried by organized labor as a subordination of human rights to property rights. The "functional approach" avoids such issues because it is based on the public interest, rather than on the vested legal rights of one party.

\section{The Union's Function Under a Labor Contract-The Watch Dog}

During the life of the contract the union's concern is to see that management, in its everyday operation of the plant, does not violate the contractual policy. The union's function can properly be considered to be that of "watch dog," in contrast to the management's function, which is to carry the responsibility as the "acting" party for efficient operations.

If being the watch dog is the union's function, then the union must have the right under the contract to perform this function. The grievance procedure established by the contract provides the method by which the union challenges manage-

${ }^{52} 16$ WAR LAB. REP. 633, 637 (1944).

s2 "Ownership is synonymous with control." City of Chicago v. Dorband, 297 Ill. App. 617 (1938). "An essential attribute of ownership is control." Standard Oil Co. of N. J. v. Powell Paving and Contracting Co., 144 S. C. 354 , I42 S. E. 612 (1928). 
ment on the ground that it has not followed the contract. Since the handling of grievances and the voluntary arbitration which commonily constitutes the final step in the grievance procedure are considered elsewhere in this symposium, ${ }^{54}$ their discussion here must be limited to a brief statement of their purpose and function in the light of the general principles which should govern the collective-bargaining process.

\section{Arbitration and the Grievance Procedure}

The purpose of the grievance procedure is simply to provide a method whereby the union can obtain compliance with the contract itself. It should not be a method by which the union questions all of management's decisions, nor should it be written so that the union can force management to place questions of managerial judgment before outside arbitrators who bear none of the responsibility for mistakes of judgment. A "grievance" should be considered simply as an allegation that management has not properly followed a given provision of the agreed policy.

The grievance should be reviewed through a series of orderly steps, the first of which is normally a meeting between the aggrieved employee and his foreman. While the union steward should participate in this meeting if the employee so desires, union efforts to provide that the matter shall be handled solely through the steward as intermediary, without personal contact between foreman and employee, should be resisted, since the foreman is charged with the responsibility of maintaining morale and efficiency. ${ }^{.5}$,

In the second step the union is permitted to present the grievance to a higher management representative if it has not been satisfactorily disposed of by the foreman. At this stage the grievance should be stated in writing, and should be answered in writing by the management representative after conference with the union representatives. Time limits should be fixed both for the presentation of the grievance and for management's reply.

A further opportunity for appeal should be provided if the grievance is not disposed of at the second stage. Again the appeal should be taken within a limited period of time, and at this stage the reasons for the appeal should be stated in writing. If no conclusion is reached at this stage it is normal for the matter to be submitted to arbitration.

If contracts are written clearly the risks of arbitration will be kept to a minimum, since the arbitrator should have only the right to interpret the contract. The War Labor Board consistently limited the arbitrator's function to questions of in-

st See Katz, Minimizing Disputes Through the Adjustment of Grievances, and Frey, The Logic of Collective Bargaining and Arbitration, supra.

${ }^{s 5}$ See NLRB v. North American Aviation, Inc., 136 FED. $2 d 898$ (C. A. A. 9th 1943); Hughes Tool Co. v. NLRB, I47 Fed. 2d 69 (C. A. A. 5th 1945); Celanese Corp. of America, I7 War LAв. Rup. 510 (1944); Kent-Owens Machine Co., 14 War LAB. Rep. 520 (1944); Art Metal Construction Co, 7 WAR LAB. Rep. 137 (1943); Aluminum Co. of America, 12 WAR LAB. REP. 446, 454 (1943). 
terpretation and application of the contract, ${ }^{56}$ and the President's Labor-Management Conference in November, 1945, unanimously went on record against giving the arbitrator power to add to, subtract from, or modify any of the terms of the agreement. ${ }^{6 \sigma^{2}}$

The function of the arbitrator being to interpret and apply the agreement, the paramount importance of clear and specific drafting should be obvious. A provision that "the company will provide as safe and sanitary working conditions as possible," perhaps reflecting the company's pride in its safety record, is an extremely loose standard under which an arbitrator might rule, for example, that a union request for air conditioning should be granted. The company should provide some such clause as the following: "The company will provide safety appliances in accordance with the state labor laws and sanitary conditions consistent with standard industrial practice."

Wage increases involve the exercise of managerial judgment and should not be submitted to arbitration. The contract should set forth the rate ranges for the various job classifications, or should specifically exclude wage questions from the arbitration clause. Such clauses as "any inequalities in wage rates will be handled under the grievance procedure," surprisingly common in collective agreements, may open the entire wage structure to arbitration unless the contract establishes a definite, objective standard by which inequalities can be determined.

Clauses requiring employers to "continue in effect all benefits in effect on the date the contract is signed," or to "perpetuate previously granted privileges and benefits," obviously lead to misunderstandings and were uniformly denied by the War Labor Board. .77 $^{\text {W7 }}$

Obtaining courageous and intelligent men as arbitrators is a very practical problem. Dependence on fees tends to put pressure on the arbitrator to reach a solution by compromise, so as not to lose favor with either party. Ideally, arbitrators should be salaried men with tenure like that of federal judges. The steps being taken by the United States Conciliation Service to develop panels of disinterested arbitrators are steps in the right direction; and the publication of arbitrators' decisions furnishes an additional safeguard.

If unions conceive of themselves as standing on their own feet and as an effective factor in the national economy, it seems odd that they should ask the employer to pay their representatives for time spent in handling grievances on behalf of employees. Reasons for paying the union steward in the appeal steps of the procedure

\footnotetext{
so Anomosa Poultry \& Egg Co., I8 War LAB. Rep. 353 (1944); Independent Produce Co., I8 Was LAB. Rep. 388 (1944); Lewittes \& Sons, I5 WAR LAB. REP. 454 (1944); Mills Novelty Co., 14 War LAB. Rep. 654 (I944); Western Electric Co., II WAR LAB. ReP. 537 (1943); Borg-Warner Corp., 6 WAR LAB. REP. 233 (1943).

sen The President's National Labor-Monagement Conference, D. L. S. BuLL. No. 77 (U. S. Dep't Iabor, 1946) 46.

"rT Coca-Cola Bottling Co., 20 WAR LAB. REP. 575 (1944); Illinois Bell Telephone Co., 15 Wax Las. Res. 94 (1944); Western Union Tel. Co., 6 WAR IAs. ReP. I33 (1943).
} 
in particular are not at all clear. The War Labor Board approached this problem functionally. In the McQuay-Norris Manufacturing Company case ${ }^{58}$ the board said:

There are cogent reasons why, as a general proposition, a union should pay its officers and its committeemen for representing employees. Such union representatives have a function to perform which should be carried out on an independent basis.

Many unions emphatically reject the idea that management should pay union representatives acting in the performance of their duties; in such payments the emotions of paternalism are most vividly revealed. Some managements which bitterly dislike unionism are among the first to agree to give stewards full pay for grievance and bargaining activity-because they think of the stewards as their employees and as members of their family. Relations are better in the plants of employers who, accepting unionism as an established fact in modern business; treat the union as an independent bargaining agency standing on its own feet, and require the union members to bear the cost of such an agency.

The argument for compensation of stewards is that management is as much interested as the union in removing grievances. Such an argument might justify half pay for time spent in handling grievances, but does'not justify any payment for time spent in contract negotiation. Since the handling of grievances may well be more attractive than working at a machine, it is important in considering the question of payment to union representatives to avoid possible incentives to spend more time than is necessary in handling grievances, or even to the stimulation of grievances in the plant.

\section{E. The NoStrike, No Slow-Down Clause}

Since the labor agreement is a contractual policy for a period of time, it should be lived up to by both parties. The grievance procedure is the union's method of obtaining compliance with the contract by the "acting party," that is, the management. Therefore, when the contract contains a final and binding arbitration clause there is no need for a strike to enforce compliance.

The most important thing that the union can give to the employer in the contract is its pledge that the employees will not strike during the life of the contract. Hence the no-strike pledge is the basic consideration flowing from the union to the company for the contract. Since this is the basic consideration, the management should have the right to compel the union and the employees to live up to their part of the contract.

For these reasons all possible enforcement provisions should be incorporated into this clause. For example, unions should be liable for money damages ${ }^{52}$ and legisla-

${ }^{88} 9$ WAR LAB. Rep. 538 (1943).

60 The United Steelworkers, CIO, finally approved a contract provision requested by the Murray Compeny of Dallas, Texas, which permits damages to be assessed by an arbitrator for work stoppages in violation of the contract. Business Week, Nov. 16, 1946, p. 15, col. 1. 
tion should be passed to make them suable at law; ${ }^{60}$ individuals who engage in strikes should be made subject to a fine which is deducted from their wages; the maintenance-of-membership clause, if there is one, should terminate automatically if there is a strike; and the employer should have the full right to discharge employees for striking.

Even if this last provision is not set forth expressly in the "no-strike" clause, the company has the right to discharge strikers if there is a "no-strike" clause in the contract. ${ }^{01}$ This was the holding of the United States Supreme Court in the Sands Manufacturing Company case. ${ }^{62}$ The War Labor Board also held that the strike leaders could be singled out and discharged, ${ }^{63}$ and arbitrators have sustained discharges of strike leaders. ${ }^{64}$

The so-called "company security" clauses are merely attempts on the part of management to obtain compliance by the unions with their basic pledge in the labor contract. Therefore, it is surprising that unions go on record against such provisions. For example, the United Automobile Workers in its Policy Statement (April, r946) said:

We stand unalterably opposed to, and will struggle to prevent or eliminate, any and all types of arbitrary penalty systems which the corporations have falsely labeled "company security." Such arbitrary penalty systems undermine normal collective-bargaining relations which are essential to effective and genuine settlement of labor disputes.

After all, the public is interested in industrial peace, and the National Labor Relations Act was enacted and its constitutionality sustained in the belief that the right to organize and bargain collectively would reduce the number of strikes which interfere with interstate commerce. This concept of the purpose of the Act, and the position set forth herein that the pledge not to strike is the consideration for the promises of the employer, received a body blow in a recent report by an NLRB trial examiner. "The examiner stated that since "the right to engage in concerted activities is ... a public right established by the Act, ... obviously employers cannot set at

${ }^{\circ}$ Voluntary associations, including labor unions, are not regarded as legal entities for purposes of suit in many states. Wilson v. Airline Coal Co., 215 Iowa 855, 246 N. W. 753 (1933); Grand International Brotherhood v. Green, 206 Ala. 196, 89 So. 435 (I921); Smith v. I. L. G. W. U., 58 Ga. App. 26, 197 S. E. 349 (1938). The rule of the Federal Courts is that they are suable if the law of the state in which the action is brought permits suit. Busby v. Electric Utilities Employees Union, I47 FED. 2d 865 (App. D. C. 1945).

"2 Many contracts are conditional no-strike agreements in that they are agreements by the union not to strike until the grievance procedure has been exhausted. Such clauses make disciplinary action. most difficult because a question of fact is involved: that is, whether or not the grievance procedure has been exhausted.

" NLRB v. Sands Mfg. Co., 306 U. S. 332 (1939). See also NLRB v. Columbian E. \& S. Co., 96 FED. 2d 948, 952-954 (C. C. A. 7th r938); United Biscuit Co. v. NLRB, 128 Fed. 2 d 77r, 774-776 (C. C. A. $7^{\text {th }}$ 1942).

"Norge Machine Products, I4 War LAB. Rep. 367 (1944), i5 War Lab Rep. 651 (1944). See also Paragon Products Co., I8 WAR LAB. REP. 722 (1944).

"Fruchauf Trailer Co., I LAB. ARB. Rep. 155 (1944); Borg-Warner Corp., 4 LAB. ARB. Rep. 4 (1945); Robert-Shaw Thermostat Co., I4 L. R. R. MaN. 2621 (1944).

is See 19 L. R. R. 305 (1947). 
naught the Act by coercing labor unions, as a price of a contract, to disregard the statutory rights guaranteed to the employees they represent." The examiner recommended that the board find the employers guilty of the unfair labor practice of refusing to bargain in good faith because of their insistence on the basic pledge not to strike. This report, if sustained, will destroy completely the stability in labor relations which should be a primary product of the collective agreement.

\section{F. Job Security and Preference Provisions}

Employees have a latent fear of insecurity. This fear motivates a demand for job protection. The job protection provisions are found in the "seniority provisions" of the contract.

Seniority is essentially a policy or rule that the employee who has worked for the company a longer period of time has a prior right to a job at time of lay-off over another employee who has worked for the company for a shorter period. This concept sounds fair because it is based upon the simple rule, "first come, first served." However, approaching the question of seniority from the point of view of basic principles, we must be sure that it does not permit a work force to grow old and incompetent and that it does not prohibit the assimilation into the work force of younger, more active employees needed to keep the plant at maximum efficiency.

In addition to job protection, seniority provisions also cover job preferences. The unions claim that the oldest man in point of service has the first right to promotion. Length of service is urged as the sole basis for wage increases within the rate range for a given job classification. To protect one man's job over another because he has been there longer is one thing, but to promote a man to a more highly skilled and better paid job merely because he has been there longer than the other candidates for the job is another matter. With these distinctions in mind, let us examine the various applications of seniority to see whether they are consistent with the basic principles.

Industry, by and large, has not had enough experience with seniority to determine whether it has damaging effects. Observation of seniority in operation in other situations, however, does make the possibilities of injury to efficiency quite apparent. Civil Service rules, which are essentially rules to protect job security and, as such, are seniority rules, interfered with efficiency in the veteran's hospitals until General Bradley had special legislation passed lifting restrictions on the removal of incompetent employees. That the railroads have suffered from too much seniority is indicated by the fact that a man sixty-eight years old was at the throttle when the "Exposition Flyer" was involved in a serious accident at Naperville, Illinois, last spring. A system of examinations was substituted for seniority as the basis of promotion in the Detroit police department when studies showed that the younger, abler, and more intelligent patrolmen were leaving the force rather than wait for someone to die in order to make room for their advancement. Such illustrations of the operation of seniority as it operates in other fields constitute a warning. The public cannot 
afford to permit a slow paralysis of industry to set in because of over-emphasis on length of service rather than merit, especially in promotions. Daniel T. Pierce, assistant to the president of Sinclair Oil Company, has said: ${ }^{\text {s5 }}$

Over a period of years the employer in a seniority straight jacket, would find himself with a lot of old men who had laboriously climbed up from the ranks and had no greater ambition than to "get by" until retired. No new blood could be introduced into the organization except at the bottom of the ladder. The last man hired must be the first man fired in a lay-off, even if he is the best man on the job. No decent employer wants to scrap old and faithful employees, nor would he do so even if no seniority rules existed. But employers would do well to examine the seniority clause with great care; otherwise they may find themselves in a situation where promotions in all standard operations must be made on length of service only; and with an argument on their hands every time an out-of-line promotion is made. Worst of all is the deadening hand of the seniority fetish on ambition and unusual capability.

If a proper balance is maintained between length of service and merit and ability in the basic test for job protection and job preferences the decay can be avoided and at the same time the desires of the employees can be recognized.6 ${ }^{68}$ The Army and Navy on July 18, 1942, issued a policy statement covering the plants they operated. This policy was endorsed by both the AFL and CIO and contained the following provision: "Seniority shall be a determining factor in matters affecting layoff and reemployment only if other factors of ability and aptitude are equal."

Interestingly enough, one individual who has had considerable experience with experimentation in social planning agrees most forcefully that merit must be recognized in the administration of wages (which includes promotions). This individual is Joseph Stalin. He said in a speech to the Russian factory managers on June 23, 1931::87

In a number of establishments the wage rates are established in such a manner that the difference almost disappears between qualified labor and unqualified labor. ... The unqualified laborer is not interested in becoming a qualified laborer.... The qualified worker is forced to move from plant to plant in order to find such a plant finally as values qualified labor.

If labor contracts cause the ambitious and able employee to lose incentive and his desire to obtain promotions to higher rated jobs because they contain a "straight" seniority plan on promotions, the public interest will not be well served.

The manner in which a seniority plan is established has a great bearing on whether or not merit and skill receive proper recognition. Under "plant-wide" plans the merit and ability test must be used more often and hence is exposed to the greatest strain. Under "job" seniority plans the merit and ability test is used less

${ }^{05}$ How the Union Disillusioned Us, Factory Man. and Maint., Jan. 1946, p. 94, col. I; p. 97, col. x.

os Time and time again the National War Labor Board included in its orders definitions of seniority with more emphasis on ability than on length of service. See Montgomery Ward \& Co., 4 War. Las. REP. 277 (1942); Dallas and Golden Belt Mfg. Cos., 3 WAR LAB. Rep. 142 (1942); Automatic Transportation Co., 8 WAR LAB. ReP. I (I943); General Motors Corp., II WAR LAB. ReP. I67 (I943).

" Abram Bergson, The Structure of Soviet Wages (1944) 178. 
often and hence yields its maximum protection. A compromise between these two types is found in "departmental" or "occupational group" seniority plans. The more seniority groups there are in the seniority plan, the less likely it is that an unqualified employee will become a candidate for promotion to a job he cannot perform.

After the right to consider an employee's individual merit in cases of promotion is obtained in the contract it should be implemented by proper "merit rating" methods. The so-called "merit rating plans" which consist of charts containing many squares following words like "qualification," "attitude," "quality," and "quantity" do not perform this function properly. Such charts are better than a mere guess but are unpopular because they are considered by unions and employees to be plans which merely cover up the favoritism involved in promotions. Some leading companies, however, without unnecessary administrative burden, have developed methods of measuring relative ability on a highly objective and factual basis. Adopting such objective tests so as to rule out the possibility of favoritism is the best method of protecting the "ability" factor in labor contracts and is certainly the best method of developing the facts to win an arbitration case.

$\mathrm{V}$.

\section{The Wage Question}

Thus far, the one basic principle which we have considered most often, in connection with the various provisions of a labor contract, is the first principle, which is: collective agreements must not be permitted to interfere with industrial efficiency. In considering the question of the general wage levels established in collective contracts, we necessarily concern ourselves with the second and third principles, the maintenance of the proper incentives for job creation and the maintenance of adequate buying power.

This shift in the basic principles involved comes about because most of the provisions of a contract, except the general wage level provisions, affect the day-today operations in the plant before the goods are produced and sold to the customer. Hence, their influence upon plant efficiency is the prime consideration. The general wage provisions, on the other hand, involve the division of the income received from the sale of the products (that is, the division of the sales dollar between the wage earner and the investor) and the question whether the income from sales should be increased by a price increase. The wage level problem, therefore, calls the second and third principles into play.

It is necessary that this division of income be properly made. Sumner H. Slichter has stated the problem as follows:

The effect of collective bargaining upon the maintenance of employment will depend in part upon how it affects investment opportunities in specific areas. ... There is reason to believe that the wage policies of the building trades have limited investment in that field. To that extent the wage policies of the building trades have injured the standard of living for the nation. ... Wisely and moderately used, collective bargaining may 
turn out to be an effective instrument for stimulating industrial research and improving management. On the other hand, collective bargaining may reduce the return on investment to such a low level that large quantities of savings are kept in idle cash and will be an obstacle to a higher standard of living.

\section{A. Profits Should Not be a Criterion for Wages}

The risk in collective bargaining in so far as public welfare is concerned is that the investor's share will be reduced to such a point that new money will not flow into new enterprises and unemployment will result. In order to protect the share of the investor and to implement the second principle, the negotiating parties at the conference table must not make the profits of an individual company a criterion for establishing wage levels.

This principle was first recognized by the War Labor Board, but in reverse English.

In the Detroit and Cleveland Navigation Company case ${ }^{68}$ the management con-. tended that it could not pay the wage increase ordered by the board because to do so would be to force the company further into the red. The board, however, said:

The panel and the Board fully understood and took careful account of the fact that the company is operating at a loss, and has been doing so for many years. The panel's recommendation has been approved on the familiar principle that, from the practical point of view of getting the service of the workers and from the more general point of view of equity and good conscience, an award of this kind should not provide a wage scale below the prevailing rate merely because the employer is unable to pay the going rate of wages in his labor market.

The increase was ordered in spite of the fact that, as the board said, "It is true that this well-accepted rule may in particular cases, and perhaps in this case, substantially affect the company's ability to stay in business. . . ."

This decision shocked industry and heaped upon the board intense criticism. It was claimed that the board, by such decisions, would destroy American industry. However, the board was consistent in its position and held that even though a company's profits were large that fact presented no reason why a wage increase should be granted. ${ }^{69}$ Corporate balance sheets were almost unknown in board proceedings. Thus the board, ruthlessly if you will, decided in no uncertain terms that the profits of a company had nothing whatsoever to do with the wages which that company should pay.

The reasoning followed by the War Labor Board received a severe shock in the statement of President Truman in December, 1945, in which he said:

In appointing a fact-finding board in an industrial dispute, where one of the questions in issue is wages, it is essential to a fulfillment of its duty that the board have the

“ 2 War Las. Rep. 68, 69 (1942).

" Ability to pay was expressly declared not to be a factor in wage rate setting by the War Labor Board. Galveston Model Laundry, 26 WAR. LAB. REP. 224 (1945); Belle Alkali Co., 13 WAR LAB. REp. 325 (1943). 
suthority, whenever it deems it necessary, to examine the books of the employer. . . . Ability to pay is always one of the facts relevant to the issue of an increase in wages. ${ }^{00 *}$

This point of view was rejected by General Motors Corporation when its representative, Walter Gordon Merrit, withdrew from the fact-finding panel with this statement: ${ }^{70}$

With this background and the revolutionary and uncompromising character of the union's proposals in mind, the corporation is unwilling to participate in the proceedings of this fact-finding board so long as its prices, profits and ability to pay-which are not facts but forecasts and estimates for the future-are to be regarded as proper factors in determining wages as applied to an individual business.

If profits become a criterion for setting wages, eventually a formula will be established to determine what percentage of the profits the risk takers (or owners) are entitled to. If such a formula were established, the pressure exerted by strong unions would make the share going to the owners smaller and smaller and would in time reduce, if not remove, the important profit incentive. ${ }^{71}$

In order to protect this principle-that profits are not a criterion for wages-it would seem that industry must recognize that it works both ways, and not attempt to force wages down solely because profits are reduced. The imposition of such reductions would justify the union in requesting wage increases if profits went up. Thus again profits and wages would be connected.

Using profits as a criterion for wages would satisfy neither the unions nor the employees. If General Motors had to pay a higher wage than Hudson because it made more profits, employees of the Hudson Motor Car Company performing the same type of work would complain bitterly that their union had taken a position which discriminated against their best interests. Furthermore, such a differential in wages could not exist, because the Hudson Motor Car Company would eventually be forced by the law of supply and demand to pay a comparable wage for comparable work. Using profits as a criterion would put a penalty upon efficiency and would therefore strike at the heart of the-national standard of living. The tremendous publicity given to profits as a method of determining wage levels was largely a publicity venture designed to. appeal to the rank and file employee, but the concept cannot stand the test of careful analysis. ${ }^{72}$

\section{B. The Cost of Living}

When the cost of living is rising, unions ask for wage increases to offset the rise. This seems a reasonable demand and certainly a natural one. All individuals would like to prevent a drop in their real wages. Nevertheless, if all groups of individuals

"ra N. Y. Times, Dec. 21, 1945, p. I4, col. 3.

${ }^{70}$ N. Y. Times, Dec. 29, 1945, P. 2, cols. $1,4$.

${ }^{7 x}$ This problem is directly presented in the Nathan report, the ClO statistical study for the 1947 wage drive, which contends that all profits over $2.9 \%$ of net worth should be taken by the wage earners through wage increases.

${ }_{73}$ For a complete analysis of the question of profits and wages, see Fred Rogers FairchuLd, Propms aNd the ABILITY to PAY Wages (1946). 
attempt to prevent a drop in real wages by raising money wages as the cost of living increases, their efforts will fail. A rise in the cost of living means that there is more money available to buy goods than there are goods to buy, and an increase in wages under such conditions merely aggravates the difficulty.

The unions know the weakness of this theory because they do not subscribe to it when the cost of living goes down. The UAW-CIO, in its National Policy Statement (April, I946), said:

We oppose any plan to cut workers' wages if living costs decrease by a certain percentage. Such a wage-cut plan was incorporated in a St. Louis contract signed by the Garment Workers' Union. It must not be incorporated in any UAW-CIO contract.

In $x$ g2r, when the cost of living was decreasing, the report of the Executive Council of the AFL contained the following statement:

The practice of fixing wages solely on the basis of the cost of living is a violation of the whole philosophy of progress and civilization, and, furthermore, is a violation of sound economic theory and is utterly without logic or scientific support of any kind.

Small craft unions are able to keep their real wages constant by increasing money wages without greatly affecting the national economy, but when large industrial unions follow this theory the amount of additional money put into the hands of consumers by wage increases causes the prices of all products to go up. This was clearly demonstrated in the Basic Steel settlement of $181 / 2$ cents, which was followed immediately by a price increase in February, $1946 .^{73}$ It was also demonstrated in the coal strike where the wage settlement was immediately followed by a price increase in coal. ${ }^{74}$ The price increases in these basic industries affected the costs of all other industries and necessitated increases in prices for consumer products. Furthermore, these basic industry increases, along with increases in oil, packing, automobiles, and other key industries, set a so-called national wage pattern of $181 / 2$ cents which spread the increase throughout industry and raised nearly all prices. ${ }^{75}$ The remedy for a rising cost of living is not higher wages, but more production and more efficiency. ${ }^{\text {70 }}$

\section{Industry Wage Scales}

Unions often demand that all employers in the same industry pay the same wage

${ }^{72}$ Price relief averaging $\$ 5.00$ per ton was granted to the steel industry simultaneously with the wage increase of $181 / 2$ cents. Daily Labor Rep. (BNA) A-r3 (March I, 1946).

"Coal price increases were granted simultaneously with the wage increase granted by the government after the coal mine seizure, equal to $\$ 1.35$ per ton for coke, $\$ 0.40$ to $\$ 1.15$ for hard coal, and So.ro to \$1.47 per ton for soft coal. Daily Lab. Rep. (BNA) AA-5 (June 28, 1946); A-2 (June 25, 1946); A-2, E-I (June 21, 1946).

${ }_{95}$ The Eighth Report of the Director of War Mobilization and Reconversion, October I, 1946, stated that the average increase approved by the National Wage Stabilization Board between February 15 and June 30, 1946, was 14.7 cents, or slightly more than 3 cents less than the pattern of big industries.

"William Green, President of the AFL, disregarded rank and file desires and advised his members in July, 1946: "In this crisis labor must exercise iron self-discipline and restraint. We must refrain from causing any interruption of production, because production alone can save us." Chi. Daily News, July 30, 1946 . 
rate for similar jobs. ${ }^{77}$ This is a natural request because it seems, at first, to be a request that wages be taken out of competition. The fallacy in this theory lies in the fact that differentials in wage rates between distant areas reflect differences in the productivity of the available labor in those areas, differences in transportation costs, differences in capital investment in the areas, and differences in labor supply. Geographic wage differentials tend to cause the flow of labor and capital into the areas where they are needed most. Hence industry-wide wage scales would tend to monopolize industry. Production would tend to concentrate in the geographic area having the maximum natural advantages and the most skilled employees. ${ }^{78}$

\section{The Productivity Theory}

As technological improvements are introduced into an industry, the unit cost of manufacturing diminishes. This saving in cost can either result in a decrease in price, an increase in profits, or an increase in wages. Statistics show that between 1840 and 1940 hourly earnings of non-agricultural workers rose about nine-fold, whereas the index of wholesale prices rose about to per cent. Since this period was one of tremendous technological improvement, it demonstrates that the wage-earner has received the benefit of increased productivity due to capital investment, which has constantly improved the machines used in industry. Some observers believe that the increased productivity of an industry can be projected into the future and that wages can go up against this normal increase in productivity each year. This increase in productivity has been estimated roughly at 3 per cent per year. ${ }^{80}$ Such a theory sounds good, but the variations from industry to industry, company to company, are so great that an application of the theory is impossible. ${ }^{81}$ This comment should not be taken to mean that productivity and wages are not directly related, but merely that the relationship is not sufficiently constant to support a wage theory.

${ }^{77}$ See the UAW-CIO National Policy Statement, Daily Lab. Rep. (BNA) E-1 (April 19, 1946).

78 The War Labor Board established wage rates on the basis of area rate comparisons, rather than industry rate comparisons. In General Motors Corp., Case No, II1-6920-D (October 9, 1944), the board rejected the industry rate comparison approach in a case involving the Delco-Remy Plant at Anderson, Indiana. The labor members of the board dissented, stating that the decision was "neither good economy nor good sense," and that "should such a policy be persisted in, the result will be the drastic weakening of the union bargaining strength, not only in the war period but especially in the postwar era."

Similarly, the National Board stated in the Basic Steel decision: "The union requests Board approval of a principle, stated as 'equal pay for similar work throughout the industry' to be used as a guide in collective bargaining for the elimination of wage rate inequities. This request of the Union is denied .." 19 War Lab. Rep. 568, 573 (1944).

so "Workers can expect to gain little by appropriating income at the cxpense of property because only about one-fifth of the national income goes to property. Furthermore labor as a whole cannut expect technological progress to raise wages more than about 3 per cent a year-unless industrial research achieves results far faster in the future than in the past. Any group which seeks to push wages by more than about 3 per cent a year is simply seeking to raise its income at the expense of other groups." Slichter, Trade Unions in a Free Society, Daily Lab. Rep. (BNA) D-1, 9 (October 8, 1946.)

a Solomon Fabricant, Employment in Manufacturing, 1899-1939 (1942) 102-104. Among 38 manufacturing industries, output per man-hour rose more than four times between 1909 and 1937 in two, but less than $67 \%$ in seven industries. 


\section{E. Area Wage Rates}

There is only one objective test which properly can be used as a guide in wage setting. That is the wage rates paid in the labor market area concerned for comparable skills. This test simply reflects the basic law of supply and demand. If the wage rates in a community are high relative to those in other places, it is because the community is a favorable location for certain growing industries which are attracting labor by paying high wages. If in that community there is a company which cannot pay the prevailing wage rate, it is denying the labor which it uses to the more productive industry. The result is that it must either pay the prevailing wage rate of the community or move to some other location. If it moves, its labor force will be free to move into the more productive company, and the public interest will be better served by such a move.

Some companies are making an effort to apply this single test to the question of general wage levels. These companies select, with their unions, a list of companies in the community with which they compare wage rates. The company obligates itself, during periods when the wage question is open for negotiation, to review with its union these comparative figures and to adjust its wage level up or down in accordance with the results of the survey.

\section{F. The Basic Factor Which Sets a Wage Level Under Collective Bargaining}

The theories of wages discussed above are used in collective bargaining usually to find some objective reason for an offer or counter offer. Unions have a right to ask that a given company raise its wages above the level of community wages. They have a right to ask that the employees receive a greater share of the income received from the sale of products. How much of this increased share, if it is granted, should be given at the expense of the consumer or investor cannot be determined on a factual basis. The proper amount of profit accumulation for an established public utility or railroad would not satisfy the needs of the risk-taking investor in new enterprises such as television or the manufacture of helicopters. The investors in such fields must have a greater possibility of reward than investors in an established industry. How much this reward shall be to keep a given industry in a healthy condition and permit it to expand properly is not a factual question, but one of judgment. Therefore, when a union demands a wage increase which will bring it above the community wage level, the questions that immediately arise, if the increase is to be granted, are whether the share of the investor shall be diminished or the price to the consumer shall be increased. The government by announced policy should refrain from intervening at this point in the collective bargaining process, because third parties cannot make the judgment decisions which must be made on this question.

The wage level will be fixed at the point beyond which one of the two parties is unwilling to fight. If the union's willingness to strike exceeds the employer's willingness to stand a shutdown, the wage increase will be granted. If the em- 
ployer's willingness to stand a shutdown exceeds the union's willingness to strike, the wage increase will not be granted.

If our economy is to be free we cannot permit boards, even of impartial men, to decide the most sensitive question involved in our national economy. Therefore a strike for a wage higher than the community level should be recognized as a "profitprice strike," and the parties should be permitted to settle the matter themselves.

VI.

\section{Conclusion}

The public interest is involved as much in the agreements reached by the parties in collective bargaining, as it is involved in the strikes that result when they fail to reach an agreement. The strike is far more spectacular, but agreements which are contrary to the public interest can be far more damaging, even though their effects are more subtle than the chaos created by a national strike.

The compromise method of settling labor disputes without any principles makes agreements more difficult to reach because the demands of the unions become insatiable. To correct this condition certain basic principles must be adopted to establish the limits on this compromise process. When this is done, both parties will approach collective bargaining with a different frame of mind, agreements will be more readily reached, and strikes will be averted.

Because the parties to collective bargaining may not voluntarily accept these basic principles soon enough, they should be made applicable by legislation. This legislation should be "prohibitive legislation." By this we mean that the legislation should declare that agreements. of a certain type are contrary to public policy and are unenforceable and void. This type of legislation, designed to protect the public interest, is exemplified in the Lea Act, ${ }^{82}$ which declared that a union demand that a radio station employer hire more persons than he needs is contrary to public policy. That Act may be unconstitutional because it was legislation designed for a special class of case, ${ }^{88}$ but the theory of the legislation was sound.

If proposed legislation controlling collective bargaining is prohibitive legislation rather than legislation establishing boards and tribunals which will make the decisions for the parties, collective bargaining can continue to operate within circumscribed but workable limits. It is more consistent with the American way of doing things for the legislature to say, "Thou shalt not agree as follows" than for the legislature to establish boards of individuals who say, "Thou shalt agree as follows." Once this distinction is lost, collective bargaining is gone forever and the economy becomes a controlled and directed economy. ${ }^{84}$

3260 Stat. 89, 47 U. S. C. A. $\$ 506$ (Supp. 1946).

"S United States v. Petrillo, 19 L. R. R. MAN. 2088 (N. D. Ill. 1946).

"There is doubt whether a law setung up an industrial court or board with the power to establish wage rates and provisions for labor contracts during peacetime would be constitutional. Such a court was declared unconstitutional in Wolff Packing Co. v. Court of Industrial Relations, 262 U. S. 522 (1923). Chief Justice Taft said (at 544): "We think the Industrial Court Act, in so far as it permits 
Prohibitive legislation can be designed for.many of the subject-matters involved in the labor contract to protect the public interest. ${ }^{85}$ It cannot, however, establish fixed tests which will control the question of general wage levels. Once the negotiating parties agree to meet the area wage level, the granting of further wage increases becomes a question of judgment and not of fact. Since these judgment questions cannot be decided by tribunals or be fixed by legislation, they must be decided by the parties themselves. It should be our objective to minimize the causes of strikes on all issues except wages and to permit free and unencumbered collective bargaining on that subject even though it may involve strikes.

If we are to have a free economy, we can go farther than to provide legislation designed to prevent injury to that economy by collective bargaining; if we establish boards to run the economy, it ceases to be free.

the fixing of wages in plaintiff in error's packing house, is in conflict with the Fourteenth Amendment and deprives it of its property and liberty of contract without due process of law."

Since the date of that decision, however, many events have taken place, and the concept of public danger, which is followed in construing the constitutional provisions concerning individual rights, may have been broadened sufficiently to sustain such an infringement upon individual rights.

"The proposal set forth in LUDwig TelleR, A LABOR Policy For AMERICa (1945), is an example of legislation based upon the reasoning that certain types of agreements should be declared to be contrary to public policy. 